\title{
IMPACT OF GLOBALIZATION ON TAXATION MIXES IN OECD COUNTRIES DURING 1965-2003
}

\author{
Květa Kubátová, Alena Vančurová, Michaela Foltysová*
}

\begin{abstract}
:
The aim of the paper is to explore impact of globalization on the tax mixes of the OECD countries. The research object is the tax mix of 21 OECD member countries in the period $1965-2003$.

The relation of tax mixes and globalization, which expresses oneself through a tax competition, is analysed by methods of multidimensional statistical analysis. First, the cluster analysis enables us to identify countries clusters (subgroups of the OECD group of countries) with similar tax mixes in the observed period. Consequently, the discriminatory analysis explains the reasons of the resulting grouping of the countries. Within the scope of the discriminatory analysis we take into account selected variables of globalization quantified on the basis of the globalization indices (economical, social and political index). The cluster and discriminatory analysis results confirm that the tax mixes in the OECD countries have been gradually approaching under the pressure of globalization.
\end{abstract}

Keywords: tax competition, globalization, tax mix, cluster analysis, discriminant analysis, OECD

JEL Classification: H2O

\section{Introduction}

Given the irreversible and strengthening influences of globalization in the form of expansion of global trade, investment and technological transfers and the economic integration of national economies, it is beneficial to look at the phenomenon of globalization as it relates to the changes in tax systems. National economies are under growing pressure from more perfect markets as a result of globalization and reduction of trade barriers, reduction of transaction costs, growing competition, deregulation and easier access to capital in the form of financial innovations. Determinants of globalization, which are making the world smaller both in terms of space and time, will continue to be important determinants of the future development of tax policy.

* University of Economics, nám. W. Churchilla 4, CZ - 13067 Praha 3 (kubatova@vse.cz).

The paper results from the Grant Projects financed by the Czech Science Foundation under No.: 402/05/2644 titled "The Analysis of Systems of Delivery of Public Services, and of Impact of Respective Solution on the Effectiveness of Public Expenditures (comparative analysis)" and under No.: 402/06/0187 named "The Sustainability of Public Finances". 
Researchers have formulated two key hypotheses, specifically hypothesis No. 1 stating that: "Factors exist that change the course of the tax mixes of developed countries in the same direction," and hypothesis No. 2:, indicating that "The globalization factor is one of factors changing the tax mixes of developed countries in the same direction."

The main method of this contribution is a cluster analysis, which captures the development of clusters in OECD countries based on changes in their tax mixes during a time period. The other used analysis is a discriminatory analysis, which clears up the influence of globalization factors on specific countries from the existing clusters.

\section{Cluster Analysis}

Due to the difficulty in defining the origins of clusters, a hierarchic approach to clustering was selected for the work. Within its framework it is possible to use the multi-range method (method of the closest neighbour, method of the farthest neighbour, median method, etc.). The results obtained by using various methods of hierarchic clustering often vary, because individual methods affect space between objects differently. The used method of the object group average to a great extent has yielded detailed results just like the centroid method, and so the results of the analysis are expected to be accurate.

\subsection{Review of Existing Cluster Analyses}

The use of a cluster analysis for identification of the development of tax systems is the subject of only a limited number of studies. Their detailed cross-section forms the contents of this part of the contribution.

The first and for a long time the only author who paid attention to cluster analysis of countries according to their tax systems was Peters (1991). The subject of his analysis were 22 OECD countries in 1965, for which the shares of all types of taxes in relation to total tax revenues were looked at. The result consists of 4 clusters of countries, English-speaking countries, Scandinavian countries, countries with a broad tax base (the mentioned countries use all types of taxes and their shares of total tax revenues are at about the average level of OECD countries) and Latin countries.

One interesting fact is that so defined clusters of countries emerged as early as in the 1970s, and even today this division is used in tax literature. Messere (1998) carried out a study of the development in OECD countries in the 1960s, 1970s and 1980s with the help of clusters. He divided up the groups of monitored countries according to common indicators of development into 5 non-European OECD countries, five southern European countries, five OECD countries with the highest tax burden, two varied European countries (Germany and Ireland) and the Great Britain - a special case.

Other authors in the recent period, who pay attention purely to European countries, are Kemmerling (2003), Bernardi (2003), Heinemann (1999) and Serrano (1994).

In the case of the first two authors, the results of the analyses, both from the point of view of the development of the total tax burden and in terms of the composition of the tax mix, can be considered very similar. So defined groups of countries with similar characteristics are relatively stable from a historical point of view, and these include the 
Northern and Scandinavian countries, the Rhine region and the Bismarck's continental countries and the mostly German-speaking continental countries and English-speaking countries. On the other hand, Bernardi's analysis looked at Mediterranean countries.

Serrano (1994) examined one type of taxes, specifically personal income tax. He was interested in the divergence of personal income taxes in the EU (then with 12 Member Countries). This work gives us a new view into the cluster analysis, because it examines only one type of taxes, characterized by multiple indicators, and the emerging groups of countries provide details about the tendencies of a specific type of tax.

Heinemann (1999) examines the influence of globalization on budgets (more specifically its four dimensions - the tax system, the spending system, public debt and the budget amount) in OECD countries as part of his multi-dimensional analysis.

This study most closely resembles the presented contribution, because it examines the influences of globalization in a rather broader context, but with defined taxes in the tax mix. There are fundamental conclusions from the Heinemann study that confirm the influences of globalization on tax mixes and specifically show the shift of emphasis towards taxation for non-mobile production factors (increasing consumption taxes).

The results of the presented works confirm the existence of the trend of convergence of the tax systems from the point of view of dividing taxes into direct and indirect categories.

\subsection{Cluster Analysis - Tax Mixes in OECD Countries}

The subject of this very cluster analysis is 21 OECD ${ }^{1}$ countries for which data was available for the entire monitored period from 1965-2003 (source of data is Revenue Statistics, 2005). In the work a hierarchic agglomeration cluster method is used, which measures the Euclid distance between objects. The rules of combining objects (distance measuring method) use a meter of the average of the group of objects. This means that the distance between two clusters is defined as the distance of group averages that contain these clusters. The objects of the cluster analysis are OECD countries defined with the help of the most important taxes from the tax mixes. Taxes are expressed as percentages of total tax revenues, and they include in particular these types of taxes: personal income taxes, corporate income taxes, social security contributions, property taxes and consumer taxes.

The results of the cluster analysis represent a historical crossroads in the development of tax mixes in OECD countries, and therefore they are comprised of clusters in the years 1965, 1970, 1975, 1980, 1985, 1990, 1995, 2000 and 2003. The resulting clusters are interpreted with the help a graphical illustration - dendrogram. For each monitored year there is a graph and detailed description of existing clusters.

We applied dendograms for the first and last year of the analysis (1965 and 2003).

1 Canada, USA, Great Britain, Japan, Austria, Belgium, Denmark, Finland, France, Germany, Greece, Iceland, Ireland, Italy, Luxembourg, Holland, Norway, Spain, Sweden, Switzerland and Turkey. 
Figure1

Clusters in 1965

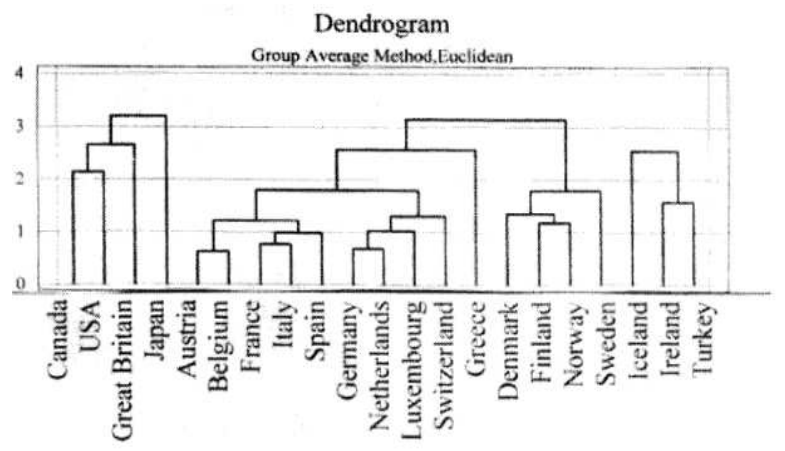

Source: Own budgets with the help of the programme Statgraphics.

In 1965 it is possible to observe 3 major clusters of these countries:

- Denmark, Finland, Norway, Sweden, Austria, Belgium, France, Italy, Spain, Germany, Holland, Luxembourg, Switzerland, Greece.

- USA, Japan, Great Britain, Canada

- Iceland, Ireland, Turkey.

The first and largest cluster includes the countries in which the tax mixes are dominated by indirect taxes, particularly VAT and consumer taxes. This large cluster, as is visible in the graph, could be divided further into smaller clusters, such as Nordic countries as Denmark, Sweden and Finland (personal income taxes are also at the same level in these countries). Tax mixes of another cluster of countries (USA, Japan, Great Britain, Canada) include non-European countries, for which a visible characteristic in this period is that their tax quota hovered below the OECD average, and the tax system was marked by an emphasis on income taxes. For the third cluster of less developed countries with a below average tax quota in comparison with other monitored countries (Iceland, Ireland, Turkey) consumer taxes tend to be dominant, with consumer taxes comprising more than a $50 \%$ share of total tax revenues.

Figure 2

Clusters in 2003

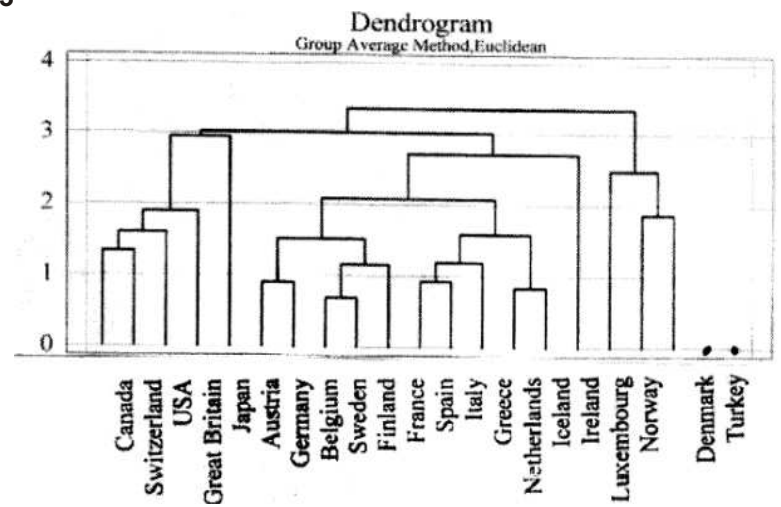

Source: Own budgets with the help of the programme Statgraphics. 
In 2003, it is possible to observe the following clusters of these countries:

- Canada, Switzerland, USA, the Great Britain, Japan, Luxembourg, Austria, Germany, Belgium, Sweden, Finland, France, Spain, Italy, Greece, Holland, Ireland, Norway, Iceland.

- Denmark.

- Turkey.

In this year, from the greatest cluster of countries two extremes can be identified, and they are Denmark with more than a 50\% share of personal income taxes and Turkey with almost a 50\% share of consumer taxes. From a historical point of view, both of these countries have always been countries with a different kind of tax systems, which corresponded to their economic, political and social conditions. Therefore, even bringing them a lot closer to the largest cluster of countries is not expected in the future. Another fact is that it is possible more thoroughly to categorize the largest cluster of countries. The existence of a sub-group of countries is visible as part of it:

- Non-European countries (USA, Japan, Canada)

- Southern European countries (Spain, Italy, Greece)

- Nordic countries (Sweden, Finland)

- European countries with a strong social foundation (Germany, Austria)

- European countries with significantly lower income taxes (Ireland, Luxembourg).

It is again true that this distribution of countries, which is based on monitoring clusters in individual years, is a constant phenomenon. Factors, that have an influence on the formation of tax systems in economic, social, historical and political terms, are one of the causes of the continuing existing clusters of these countries. Nonetheless, the recent period - the 1980s and 1990s - witnessed the merging of existing clusters of the countries into one large cluster. The explanation for this situation is in fact the subject of the work, which places emphasis on the influence of globalization and the formation of tax mixes under its influence.

The results of the cluster analysis (i.e., the cluster analyses for all of the monitored periods, the dendograms we will not show here due to a lack of space) confirm hypothesis No. 1: "Factors exists that change the course of the tax mixes of developed countries in the same direction."

The formation of clusters in the analysis highlights that during historical formation of tax mixes in countries there is a tendency for them to become closer to each other, which has intensified recently. The term "recent period" is understood to mean the years 1990 and 2000, when globalization factors obviously had a powerful effect.

The results of the cluster analysis also indicate that countries influenced by globalization are shifting their tax systems from an emphasis on mobile to one on non-mobile tax bases. Clusters of countries, created since the beginning of the monitored period, i.e. in 1965, always were marked by a strong emphasis on one type of tax revenue, and then gradually as of the 1990s in particular the tax mixes began getting closer and most of the monitored countries ended up in one cluster. The reason for this is a shift of emphasis from direct taxes to indirect taxes as part of obtaining tax revenues. The existence of specific taxes or social systems in certain 
countries (Denmark, Turkey) causes them to be "pushed out" from the cluster of the rest of the monitored countries.

The realized cluster analysis itself brings results that confirm the findings of the tax theory according to which countries can be divided up into certain groups:

- Nordic countries (Denmark, Norway, Finland)

- Southern countries (Spain, Portugal, Greece)

- Central European countries (France, Germany, Austria)

- non-European (USA, Japan, Canada, Iceland).

So defined groups of countries with smaller deviations can be found in a tax literature from authors who also have used an cluster analysis. Already for the year 1965, G. Peters (1991) defined similar clusters of OECD countries. Messere (1998) with the help of clusters defined the development in OECD countries in the 1960s, 1970 s and 1980s. Other authors, too, have worked with similar clusters of countries. For example, Kemmerling (2003) and Bernardi (2003) differentiate in their works between the identification of European countries according to their total tax quota with consideration for social security systems (Kemmerling, 2003), or harmonization trends (Bernardi, 2003). From another point of view, Serrano (1994) identifies clusters of countries according to factors of only one type of tax, specifically personal income taxes. In his work, Heinemann (1999) examined the influence of globalization on the entire state budget, of which taxes are one dimension. The methods that he used - an cluster and a discriminatory analysis - also confirm the influence of globalization, but the subject of his work was focused only on corporate and consumer taxes and only during the period from 1970-1990.

So a possible conclusion is that the results of this cluster analysis fit into existing works with a similar orientation and supplement the tax literature with a new historical view of the overall tax mixes during a lengthier period with an emphasis on recent years. The benefit is found not only in defining clusters like in the case of the authors mentioned, but likewise in pointing out the causes of their formation. The discriminatory analysis in the following chapter serves this purpose.

\section{Discriminatory Analysis}

\subsection{Review of Existing Discriminatory Analyses}

Discriminatory analyses, similarly to cluster analyses, have uses particularly in the areas of biology, geology, archaeology and medicine (Meloun etc.,2005). Their use in the economy in relation to taxes is minimal. From the available sources there is only one author, who has already been named in the group of authors using the cluster analysis, because he combined the use of an cluster analysis with a discriminatory analysis. Heinemann (1999) when examining the influences of globalization on the state budget analyses whether globalization factors have an influence on the formation of the created clusters of countries, and he does this with the help of a discriminatory analysis.

For the state budget Heinemann differentiates 4 dimensions, which are the tax and expenditure structure, public debt and budget size. Emphasis is placed on the revenue 
portion, which is under the influence of the tax competition of worldwide globalization. He understands the globalization factors purely in an economic sense and divides them into economic openness, restrictions of exchange rates and types of currency exchange regimes. The result of the analyses confirms the hypothesis that globalization is forcing governments to adapt tax systems by shifting their emphasis from mobile to non-mobile factors.

Another uses of discriminatory analysis in the economy are focused rather on sociological surveys in examining a broad database with multiple influence factors, such as the causes of forming regions, the influence of social factors when forming economic development, tracking of income inequality in terms of time and space and changes in the structure of incomes in relation to industrial sectors (the works of Kalduru and Parts 2005, Paldam and Svedson 2000, Galbraith and Jiaqing 1997, Galbraith and Kim 1998).

This very combination of a discriminatory analysis that is dependent on a cluster analysis in the work is unique and contributes to the use of an overview of multidimensional statistical methods for development of tax structures in the OECD when considering the different factors of globalization.

\subsection{Discriminatory Analysis -Tax Mixes of OECD Countries}

The first chapter describes the results of the cluster analysis - assignment of OECD countries into clusters in the monitored historic period. Has globalization truly had an influence on this arrangement of countries into clusters? The answer can be obtained with the help of a discriminatory analysis.

The discriminatory analysis is among multidimensional statistical analyses that examine the relationship between a group of independent indicators (discriminators) and a single qualitative dependent variable. Multidimensional character is captured in the analysis in the form of globalization indices. In this process the whole dimension is taken into consideration, not only its economic part like in the case of the work of Heinemann (1999).

We apply as input data the CSGR Globalisation Index of Lockwood and Redoano (2005). The overall index of globalization is formed by three sub-indices as follows:

- economic

- social

- political.

Each of these three indices is calculated with the help of specific variables. The weights of individual variabless in given indices differ as follows: 
Table 1

Weight of Globalization Indices

\begin{tabular}{|c|c|}
\hline Variables & Weight in index \\
\hline \multicolumn{2}{|l|}{ Economic index } \\
\hline Trade & $83.29 \%$ \\
\hline FDI & $2.35 \%$ \\
\hline Investment portfolio & $3.22 \%$ \\
\hline Revenues & $9.12 \%$ \\
\hline \multicolumn{2}{|l|}{ Social index } \\
\hline Share of foreign population in the total population & $6.65 \%$ \\
\hline Flow of the foreign population as a $\%$ of the total population & $0.5 \%$ \\
\hline Number of tourists as a $\%$ of the total population & $57.15 \%$ \\
\hline International outgoing telephone calls in minutes per 1 inhabitant & 0.059 \\
\hline Internet users as a $\%$ of the total population & $3.97 \%$ \\
\hline Number of imported and exported films & 310.92 \\
\hline Number of imported and exported books per 1 inhabitant & 10.08 \\
\hline Number of incoming and number of outgoing e-mails per 1 inhabitant & 15.76 \\
\hline \multicolumn{2}{|l|}{ Political index } \\
\hline Number of foreign embassies in the country & 34.16 \\
\hline Number of peace-keeping operations in which the country participates & 1.16 \\
\hline Number of memberships in international organizations & 40.70 \\
\hline
\end{tabular}

Source: Lockwood, Redoano (2005).

The total globalization index (GINDEX) is based on normalization of individual variables and subsequent clustering of their weights:

$$
\operatorname{GINDEX}_{u}=\sum_{\mathrm{j}=1}^{\mathrm{J}}=\omega_{\mathrm{j}}\left(\sum_{\mathrm{m}=1}^{\mathrm{M}} \omega_{\mathrm{m}}=\left(\mathrm{X}_{\mathrm{jmit}}-\mathrm{X}_{j m t}^{\mathrm{min}}\right) /\left(\mathrm{X}_{j m t}^{\max }-\mathrm{X}_{j m t}^{\mathrm{min}}\right)\right)
$$

Where $i$, and $t$ indicate a region and time period, $m, j$ main components of variables, $\omega_{\mathrm{m}}$ weight that belongs to each variable $X$ as part of the component, $\omega_{\mathrm{j}}$ the weight for each component, min and max are the minimum and maximum values of the corresponding variables as part of the countries in the given year.

It applies that the weights of components are selected on an ad hoc basis, and therefore there is talk about a basic index. In the basic index, each of the 13 determinants of the index has the same weight $(\mathrm{w}=1)$.

The analysis takes into consideration those OECD countries that were part of the clusters in the monitored period, but due to the non-existence of certain globalization factors the selected countries were excluded from the discriminatory function. Since the goal of the work is to point out the influence of globalization on tax mixes and it has been significant in recent years, the discriminatory analysis captures the years 1980, 1990, 2000 and 2003. 


\section{Year 1980 - discriminatory function}

The table captures input data for the discriminatory function, and these are the individual globalization indices in 1980 in the OECD countries that were part of the monitored cluster of countries. Denmark was the country excluded from the analysis due to insufficient data.

Table 2

Globalization Indices in 1980

\begin{tabular}{|l|c|c|c|}
\hline \multicolumn{1}{|c|}{ Countries } & Economic index & Social index & Political index \\
\hline Canada & 0,198 & 0,189 & 0,802 \\
\hline USA & 0,19 & 0,097 & 0,907 \\
\hline Japan & 0,189 & 0,02 & 0,655 \\
\hline Belgium & 0,326 & 0,271 & 0,861 \\
\hline Finland & 0,172 & 0,082 & 0,663 \\
\hline France & 0,206 & 0,178 & 0,941 \\
\hline Greece & 0,161 & 0,02 & 0,485 \\
\hline Ireland & 0,213 & 0,111 & 0,464 \\
\hline Italy & 0,19 & 0,07 & 0,839 \\
\hline Netherlands & 0,249 & 0,159 & 0,626 \\
\hline Norway & 0,193 & 0,077 & 0,532 \\
\hline Spain & 0,18 & 0,062 & 0,574 \\
\hline Sweden & 0,186 & 0,099 & 0,759 \\
\hline Switzerland & 0,239 & 0,348 & 0,515 \\
\hline Great Britain & 0,251 & 0,109 & 0,883 \\
\hline Denmark & 0,184 & 0,161 & 0,645 \\
\hline Iceland & 0,134 & 0,084 & 0,253 \\
\hline
\end{tabular}

Source: Lockwood, Redoano (2005), own budgets.

The result of the discriminatory analysis realized with the help of the Statgraphics programme can be used to show the very small influence of globalization factors in this period, from which the greatest influence can be viewed in the case of the economic globalization index (first value of the discriminatory function). The strength of individual discriminators is expressed with the help of the Wilks Lambda value. In case its value is close to 0 , it means the used discriminator is stronger.

Table 3

Results of the Discriminatory Analysis in 1980

\begin{tabular}{|c|c|c|c|}
\hline Discrimination Function & Eigenvalue & Ratio & Wilks Lambda \\
\hline 1 & 0,58265 & 81,09 & 0,555542 \\
\hline 2 & 0,123434 & 17,18 & 0,879229 \\
\hline 3 & 0,012396 & 1,73 & 0,987756 \\
\hline
\end{tabular}

Source: Own budgets with the help of the programme Statgraphics. 


\section{Year 1990 - discriminatory function}

Input data for the year 1990 are contained in the other charts and contain individual globalization indices for OECD countries from existing clusters. The countries excluded for insufficient data in this period are Austria, Germany and Luxembourg.

Table 4

Globalization Indices in 1990

\begin{tabular}{|l|c|c|c|}
\hline \multicolumn{1}{|c|}{ Countries } & Economic index & Social index & Political index \\
\hline Canada & 0,201 & 0,326 & 1,006 \\
\hline USA & 0,196 & 0,306 & 0,940 \\
\hline Belgium & 0,367 & 0,648 & 0,938 \\
\hline Finland & 0,176 & 0,179 & 0,808 \\
\hline France & 0,215 & 0,267 & 1,003 \\
\hline Greece & 0,167 & 0,032 & 0,555 \\
\hline Iceland & 0,134 & 0,169 & 0,255 \\
\hline Ireland & 0,241 & 0,321 & 0,645 \\
\hline Italy & 0,193 & 0,104 & 0,954 \\
\hline Netherlands & 0,251 & 0,364 & 0,696 \\
\hline Norway & 0,193 & 0,220 & 0,573 \\
\hline Spain & 0,187 & 0,092 & 0,738 \\
\hline Sweden & 0,200 & 0,284 & 0,962 \\
\hline Switzerland & 0,235 & 0,833 & 0,579 \\
\hline Great Britain & 0,253 & 0,265 & 0,943 \\
\hline Portugal & 0,189 & 0,069 & 0,675 \\
\hline Denmark & 0,198 & 0,288 & 0,787 \\
\hline Japan & 0,190 & 0,059 & 0,737 \\
\hline
\end{tabular}

Source: Lockwood, Redoano (2005), own budgets.

The result of the discriminatory analysis in this period is the gradually rising influence of globalization and mainly its economic factor, and the political index still has an insignificant influence. The results show an obvious drop in Wilks Lambda values, which in individual discriminators are beginning more to resemble zero.

Table 5

Results of the Discriminatory Analysis in 1990

\begin{tabular}{|c|c|c|c|}
\hline Discrimination Function & Eigenvalue & Ratio & Wilks Lambda \\
\hline 1 & 0,789932 & 55,35 & 0,339001 \\
\hline 2 & 0,620102 & 43,45 & 0,606789 \\
\hline 3 & 0,0172323 & 1,21 & 0,98306 \\
\hline
\end{tabular}

Source: Own budgets with the help of the programme Statgraphics. 


\section{Year 2000 - discriminatory function}

The year 2000 follows, for which there was not enough available data from countries, such as Germany, Austria, Luxembourg and Turkey. In all of the monitored countries the individual types of globalization indices grew, which confirms the expectation the influence of globalization will continue to grow.

Table 6

\section{Globalization Indices in 2000}

\begin{tabular}{|l|c|c|c|}
\hline \multicolumn{1}{|c|}{ Countries } & Economic index & Social index & Political index \\
\hline Canada & 0,252 & 0,678 & 1,259 \\
\hline USA & 0,217 & 0,217 & 1,397 \\
\hline Belgium & 0,722 & 0,672 & 1,218 \\
\hline Finland & 0,277 & 0,417 & 0,942 \\
\hline France & 0,259 & 0,283 & 1,429 \\
\hline Greece & 0,186 & 0,093 & 0,790 \\
\hline Iceland & 0,189 & 0,408 & 0,382 \\
\hline Ireland & 0,744 & 0,486 & 0,877 \\
\hline Italy & 0,231 & 0,221 & 1,188 \\
\hline Netherlands & 0,366 & 0,413 & 0,858 \\
\hline Norway & 0,242 & 0,447 & 0,799 \\
\hline Spain & 0,261 & 0,200 & 0,868 \\
\hline Sweden & 0,263 & 0,430 & 1,186 \\
\hline Switzerland & 0,321 & 0,899 & 0,890 \\
\hline Great Britain & 0,310 & 0,462 & 1,321 \\
\hline Australia & 0,195 & 0,561 & 0,703 \\
\hline Japan & 0,183 & 0,202 & 0,828 \\
\hline Portugal & 0,216 & 0,192 & 0,867 \\
\hline Denmark & 0,274 & 0,505 & 1,054 \\
\hline
\end{tabular}

Source: Lockwood, Redoano (2005), own budgets.

The result of the discriminatory analysis in this period is the already growing influence of globalization, mainly in the form of an economic index, but even the political index is beginning to have a growing tendency.

\section{Table 7}

Results of the Discriminatory Analysis in 2000

Year 2003 - discriminatory function

\begin{tabular}{|c|c|c|c|}
\hline Discrimination Function & Eigenvalue & Ratio & Wilks Lambda \\
\hline 1 & 1,32488 & 52,83 & 0,175173 \\
\hline 2 & 0,868938 & 34,65 & 0,407256 \\
\hline 3 & 0,313826 & 12,51 & 0,761136 \\
\hline
\end{tabular}

Source: Own budgets with the help of the programme Statgraphics.

The last monitored period is the year 2003, in which there was not enough available data for the indices from Germany, Austria, Luxembourg or Turkey. Even this year confirms the growing influence of globalization across growing globalization indices from all areas - economic, social and political. 
Table 8

Globalization Indices in 2003

\begin{tabular}{|l|c|c|c|}
\hline \multicolumn{1}{|c|}{ Countries } & Economic index & Social index & Political index \\
\hline Canada & 0,446 & 0,905 & 1,487 \\
\hline USA & 0,438 & 0,507 & 1,568 \\
\hline Belgium & 0,850 & 0,902 & 1,478 \\
\hline Finland & 0,399 & 0,427 & 1,322 \\
\hline France & 0,347 & 0,340 & 1,557 \\
\hline Greece & 0,244 & 0,149 & 0,930 \\
\hline Iceland & 0,234 & 0,515 & 1,491 \\
\hline Ireland & 0,833 & 0,583 & 0,966 \\
\hline Italy & 0,311 & 0,350 & 1,277 \\
\hline Netherlands & 0,453 & 0,562 & 1,140 \\
\hline Norway & 0,346 & 0,539 & 0,934 \\
\hline Spain & 0,346 & 0,318 & 0,935 \\
\hline Sweden & 0,287 & 0,499 & 1,930 \\
\hline Switzerland & 0,484 & 0,941 & 0,932 \\
\hline Great Britain & 0,504 & 0,570 & 1,656 \\
\hline Australia & 0,243 & 0,678 & 0,932 \\
\hline Japan & 0,238 & 0,352 & 1,933 \\
\hline Portugal & 0,344 & 0,299 & 1,140 \\
\hline Denmark & 0,348 & 0,632 & 1,241 \\
\hline
\end{tabular}

Source: Lockwood, Redoano (2005), own budgets.

The results of the discriminatory analysis in the last monitored period were in the predicted direction of growing influence of globalization on the monitored tax mixes. The Wilks Lambda value is closed to zero, with the exception of political factors of globalization.

Table 9

Results of the Discriminatory Analysis in 2003

\begin{tabular}{|c|c|c|c|}
\hline Discrimination Function & Eigenvalue & Ratio & Wilks Lambda \\
\hline 1 & 2,01487 & 59,26 & 0,122273 \\
\hline 2 & 1,08196 & 31,82 & 0,368637 \\
\hline 3 & 0,302955 & 8,91 & 0,767486 \\
\hline
\end{tabular}

Source: Own budgets.

The results of the discriminatory analysis, just like the cluster analysis, appear to confirm set hypothesis No. 1: "Factors exist that change the course of tax mixes of developed countries in the same direction."

These factors are those of globalization, divided into economic, social and political factors. Their individual affect on tax mixes in the last period is intensifying, mainly in the economic area. The results could have been somewhat distorted by excluding certain countries from the analysis due to insufficient data. Another factor that needs to be considered is the existence of only a limited number of OECD countries, specifically developed countries whose globalization indicators could lead to certain inaccuracy of the results. 


\section{Conclusion}

The results of the cluster analysis point to the verification of both work hypotheses. It is true that during the historic formation of the tax mixes of countries there appears to be a tendency for them to become closer to each other, and this intensified at the beginning of the 1990s, which was a period of intensifying globalization pressures. This seems to confirm hypothesis No. 1: "Factors exists that change the course of tax mixes of developed countries in the same direction." The results of the cluster analysis also further confirm hypothesis No. 2: "The globalization factor is one of factors changing the tax mixes of developed countries in the same direction." From the point of view of the composition of tax mixes it is possible to observe a shift of emphasis from direct to indirect taxes, and/or from mobile to non-mobile tax bases. The hypothesis would require further statistical verification, which however is outside of the report.

It also can be concluded that the results of the cluster analysis appear to confirm not only the work hypotheses, but also the tax theories according to which countries can be divided into certain groups:

- Nordic countries (Denmark, Norway, Finland)

- Southern countries (Spain, Portugal, Greece)

- Central European countries (France, Germany, Austria)

- Non-European countries (USA, Japan, Canada, Iceland).

The discriminatory analysis captures the years 1980, 1990, 2000 and 2003. The results of the discriminatory analysis, like the cluster analysis, appear to confirm set hypothesis No. 1. Factors that influence the process of tax mixes becoming closer are globalization factors, divided into economic, social and political factors. Their individual affects on the tax mixes in the recent period have been intensifying, particularly in the economic area (the discriminator in the form of the economic globalization index has the strongest and a growing influence).

\section{References}

Bernardi, L. "Tax Systems and Tax Reforms in Europe: Rationale and Open Issues of More Radical Reforms". Working Paper 2000/2003, Italy.

Galbraith, J. K., Kim, J. (1998), "The Legacy of HIC: An Empirical Analysis of Korean Industrial Policy”. Journal of Economic Development, 23, pp. 1-20.

Galbraith, J. K., Lu Jiaqing (1997), "Cluster and Discriminant Analysis on the Time-series as a Research Tool". UTIP WP 6.

Heinemann, F. (1999), "Does Globalization Restrict Budgetary Autonomy? A Multidimensional Approach". Center for European Economic Research, 1999. [online] http://opus.zbw-kiel.de/ volltexte/2007/5244/pdf/dp2999.pdf.

Kalduru, H., Parts, E. (2005), The Effect of Macro-level Social Capital on Sustainable Economic Development. Tartu.

Kemmerling, A. (2003), "The Political Economy of Tax Mixes in OECD Countries". Berlin : Freie Universität.

Lockwood, B., Redoano, M. (2005), "The CSGR Globalization Index: an Introductory Guide". Centre for the Study of Globalization and Regionalization [online] http://www 2.warwick.ac.uk/fac/ soc/csgr/index/.

Meloun, M., Militký, J., Hill, M. (2005), Počitačová analýza vícerozměrných dat v př́íladech. Praha : Academia. 
Messere, K. C. (1998), Tax System in Industrialized Countries. Oxford : Oxford University Press.

Paldam, M., Svedson, G. T. (2000), "Missing Social Capital and the Transaction in Eastern Europe". Journal for Institutional Innovation, Development and Transition, 5, pp. 21-34.

Peters, B. G. (1991), The Politics of Taxation a Comparative Perspective. Cambridge, MA : B. Blackwell.

Revenue statistics 1965-2004. 2005 edition (complete edition - ISBN 9264012842). OECD: Taxation, Vol. 2005, No. 6, pp. 1-339.

Serrano, A. M. (1994), "Divergences in Personal Income Taxes at a State and Local Level in the European Union: An Applied Multivariate Analysis". Rome, Italy : Regional Science Association.

Sachs, J. The End of Poverty: How Can We Make It Happen in Our Lifetime. London : Penguin Books, 2005. 396 pp.

Jeffrey Sachs, a prominent international expert in the area of economic development, who is currently director of the Earth Institute at the University of Columbia and a special UN adviser, attempts to change an approach to the issue of economic development in order to defend the ambitious Millennium Development Goals (MDG). They were approved by the UN member states in 2000 . The MDG Project specifically defines the tasks and commitments the member states have to fulfil in order to diminish extreme poverty by 2025 .

The author rejects the condensation to which development issues have been exposed in the last decades, mainly in the framework of IMF projects. The book accentuates the necessity of a complex approach to economic reforms in developing countries. It means not only the engagement in traditional problems such as economy openness, share of state ownership, government regulation or fiscal discipline, but also the consideration of objectively existing poverty, fiscal restrictions, geographic conditions, cultural restrictions or geopolicy.

Chapters I, II and III characterise the extent of world poverty at present, describe the factors of economic growth in history and identify restraints for the achievement of economic development some countries are facing. Chapter IV presents clinical economy, inspired by the clinical practice of medicine. The method consists in a complex diagnosis of afflicted economy, combined with an elimination method aimed to reveal problematic areas and causalities of problems. Chapters V to X describe successes and failures of reforms in Bolivia, Poland, Russia, China and India in contrast to the untenable situation in Africa. Chapters XI to XIV present practical proposals how to solve problems in the poorest countries. An emphasis is laid on foreign development aid and on remitment of debts from the past. In Chapter XV the financial estimation of these proposals is given. In final chapters XVI to XVIII political and moral aspects of this problem are discussed.

The book is an important contribution to development issues of the poorest countries; it is presented in a style acceptable for both the economic community and the public. Mr. Sachs tries to give specific answers to very comprehensive problems, which is, however, the critical point of the book itself and of the author's proposals.

Bořek Vašíček 